\title{
Callus formation, organogenesis and microclonal reproduction in different species of the genus Linum L. in vitro
}

\author{
S. V. Mishchenko* , L. M. Kryvosheieva \\ Institute of Bast Crops, NAAS of Ukraine, 45 Tereshchenkiv St., Hlukhiv, Sumy region, 41400, Ukraine, \\ *e-mail: serhii-mishchenko@ukr.net
}

Purpose. To reveal the frequency and intensity of callus formation and organogenesis, the effectiveness of microclonal reproduction of various species of the genus Linum L. (Linaceae) in vitro. Methods. For in vitro induction of callus formation and organogenesis, hypocotyl segments of species Linum usitatissimum L. convar. elongatum and convar. usitatissimum, L. tenue Desf., L. bienne Mill., L. corymbulosum Pchb., L. nervosum Waldst. \& Kit., L. flavum L., L. campanulatum L., L. perenne L., L. austriacum L., L. grandiflorum Desf., L. strictum L. were cultivated on Murashige and Skoog medium supplemented with $0.05 \mathrm{mg} / \mathrm{l}$ 1-naphthylacetic acid and $1.0 \mathrm{mg} / \mathrm{l} 6$-benzyl aminopurine at $22-24^{\circ} \mathrm{C}$, relative humidity of $60-80 \%$, with 16 hours photoperiod (2500 flux). For microclonal reproduction Murashige and Skoog, White, Gamborg and Eveleigh media and their modifications were used. The measurement results were interpreted by the arithmetic mean, standard error for the sample mean, the least significant difference and ranked. Results. Different species of the genus Linum to a large extend are capable of forming callus and regenerating shoots under the specified cultivation conditions. The frequency of callus formation for the studied samples on the 35th day of cultivation varied within 81.25-100\%, the mass of callus from one explant $-0.21-1.64 \mathrm{~g}$, the frequency of organogenesis $-12.50-100 \%$, the number of shoots 1.8-7.6 pcs. and the height of the shoots was $0.82-2.12 \mathrm{~cm}$. The following species: L. usitatissimum convar. elongatum, $L$. tenue, $L$. bienne and $L$. strictum were distinguished by a high intensity of callus formation. Intensive organogenesis was pecular to L. tenue, L. bienne, L. flavum, L. austriacum and L. grandiflorum. The efficiency of somaclone obtaining was quite low in $L$. nervosum and $L$. campanulatum. In total, for the microclonal reproduction of species of the genus Linum Murashige and Skoog, Gamborg and Eveleigh media supplemented with $12.5 \mathrm{~g} / \mathrm{l}$ glucose were optimal. At the final stages of microclonal propagation, before transferring microclones in vivo, it is advisable to use White medium, which contributes to a high frequency of rhizogenesis. Varieties of $L$. usitatissimum convar. elongatum and convar. usitatissimum had different responses to in vitro culture. Conclusions. The frequency and intensity of callus formation and organogenesis, the effectiveness of microclonal reproduction depended on the genotype of a particular species; therefore it is advisable to select the composition of the nutrient medium and growth regulators for each of them. Some species of the genus Linum have not yet been studied in vitro, so the obtained results allow expanding the scope of their use in practice, in particular in breeding as a new source material with somaclonal variation, interspecific crosses, and ornamental floriculture.

Keywords: Linum L.; in vitro; nutrient medium; phytohormones; shoot.

\section{Introduction}

The practical significance of the species of the genus Linum L. (Linaceae) is due to their beneficial properties. The species are used as fiber, oilseeds, melliferous, medicinal, fodder, essential oil and ornamental plants [1]. Under certain conditions, various species of this genus

Serhii Mishchenko

https://orcid.org/0000-0002-1979-4002

Larysa Kryvosheeva

https://orcid.org/0000-0001-6688-6930 can be involved in interspecific crosses with the subsequent use of such hybrids in breeding. In agrarian production, diverse varieties of flax (Linum usitatissimum L.) are common, which are mainly grown to obtain natural fiber for the textile industry, seeds, edible or technical oil.

Although flax has been known for several millennia, it still remains the subject of numerous scientific studies on phylogenesis and taxonomy, breeding and growing technology, biotechnology, etc. The culture of isolated cells and tissues can be used in practical breeding. The regenerated plants formed in vitro in compari- 
son with the starting material are characterized by somaclonal variability, which, in case of positive changes, can be used for the creation of new varieties. Undesirable mutant forms can be rejected at the stage of regeneration in vitro.

Methods of plant cells and tissues regeneration, somatic embryogenesis, anther culture and doubled haploids, isolated protoplasts, cell suspensions, etc. in breeding programs have been well designed and described precisely for $L$. usitatissimum. In particular, for the induction of somatic callus formation and organogenesis in flax in vitro, the successful experience of using 1-naphthaleneacetic acid (NAA) and 6-benzylaminopurine (BAP) [2, 3], 2,4-dichlorophenoxyacetic acid (2,4-D) and BAP [4], thidiazuron (TDZ) [5], etc. is known. In the cell suspension culture, the addition of the phytohormones NAA $(0.1 \mathrm{mg} / \mathrm{l})$ and BAP $(0.5 \mathrm{mg} / \mathrm{l})$ was optimal. At the same time, a high concentration of BAP in a liquid medium limited cell proliferation and reduced biomass formation [6]. Lowmolecular five-and six-membered nitrogen-containing heterocyclic compounds (derivatives of pyridine, pyrimidine, pyrazole, and isoflavones) have also been found to exhibit a high stimulating effect on direct organogenesis of flax, thus these compounds are promising as effective substitutes for traditional (common) auxin NAA and cytokine BAP [7].

The effectiveness of callus formation and organogenesis depends not only on the determination of optimal concentrations and combinations of auxins and cytokinins in the medium. It was higher in the case when hypocotyl segments were immersed in sterile distilled water before being placed on hormonal nutrient medium and shaken slightly for 20 minutes, compared with the option where they were immediately placed on medium. Such pretreatment softened the epidermis layer and increased its permeability, what caused a higher metabolic activity of the tissues due to increased water, nutrients and growth regulators absorption from the medium [8]. The competition among the explants was achieved by changing the distance between them in Petri dishes: in particular, at a distance of $1.0 \mathrm{~cm}$ compared with placement at $2.0 \mathrm{~cm}$, the number of regenerants and their length increased, and in the case of reducing the distance to $0.5 \mathrm{~cm}$ decrease in the frequency of organogenesis and size of the formed shoots was observed [9]; the placement of explants according to the $1.5 \times 1.5 \mathrm{~cm}$ scheme was optimal [10].

Although the anther culture is less efficient for the regeneration of flax plants, compared with the somatic cell culture, it is often used in biotechnological research. It is regenerants ob- tained from anther cells that have increased resistance against Fusarium wilt [11]. Pretreatment of donor plants, the genotype (variety), the type and ratio of exogenous growth regulators, the temperature of cultivation of explants had a significant impact on the induction of callus formation in flax anther culture. Anthers of donor plants grown under lower temperatures $\left(14-18^{\circ} \mathrm{C}\right)$ significantly increased the intensity of callus formation compared with anthers grown at higher temperatures $\left(18-22{ }^{\circ} \mathrm{C}\right)$. Combinations of phytohormones should be developed for each genotype separately. In particular, for certain varieties such combinations are described as effective: $0.1 \mathrm{mg} / \mathrm{l} \mathrm{BAP}$ and $0.2 \mathrm{mg} / 1 \mathrm{2}, 4-\mathrm{D} ; 0.2 \mathrm{mg} / \mathrm{l} \mathrm{BAP}$ and $0.1 \mathrm{mg} / \mathrm{l}$ $\mathrm{NAA} ; 0.1 \mathrm{mg} / \mathrm{l} \mathrm{BAP}$ and $0.2 \mathrm{mg} / \mathrm{l}$ indole-3-acetic acid (IAA), depending on the genotype, must be supplemented with nutrient medium with sucrose [12-14], maltose for effective regeneration of the shoots [15] or lactose, which increases the intensity of callus formation [16]. The number of anthers with callus formation was greater at a cultivation temperature of $28{ }^{\circ} \mathrm{C}$, compared with 33 and $6{ }^{\circ} \mathrm{C}$ [17].

Methods for obtaining callus tissue from the embryo (ovary) of flax, followed by regeneration of shoots are also developed. It was revealed that callus was the most intensively formed and shoots were regenerated on medium supplemented with $1.5 \mathrm{mg} / \mathrm{l} \mathrm{IAA}$ and $1.5 \mathrm{mg} / \mathrm{l} \mathrm{BAP}$, but rhizogenesis in this case was not observed, roots developed on medium only with auxin 2.4-D [18]. Other studies have shown that the frequency of callus formation can vary widely (9.17-100\%), depending on the variety and phytohormonal composition of the medium, and in some varieties, organogenesis did not occur at all. In most cases, the highest rate of shoot regeneration was obtained on a medium supplemented with $0.1 \mathrm{mg} / \mathrm{l} \mathrm{NAA}$ and $0.2 \mathrm{mg} / \mathrm{l} \mathrm{TDZ}$. Cytological analysis shows that $21.88 \%$ of the regenerated plants were haploids, and the rest were diploids or mixoploids $(78.12 \%)$ [19].

The processes of callus formation and organogenesis of L. usitatissimum in vitro are determined by genetic factors. Callus formation and the ability to regenerate are influenced by the non-additive effects of genes. At the same time, the degree (intensity) of callus formation and organogenesis has different genetic nature [20].

Representatives of the genus Linum are characterized by a significant variety of biological features, among which a special place is occupied by the structure and color of the flower (Fig. 1), the stem morphology and life form. The genus belongs to the critical and systematically 

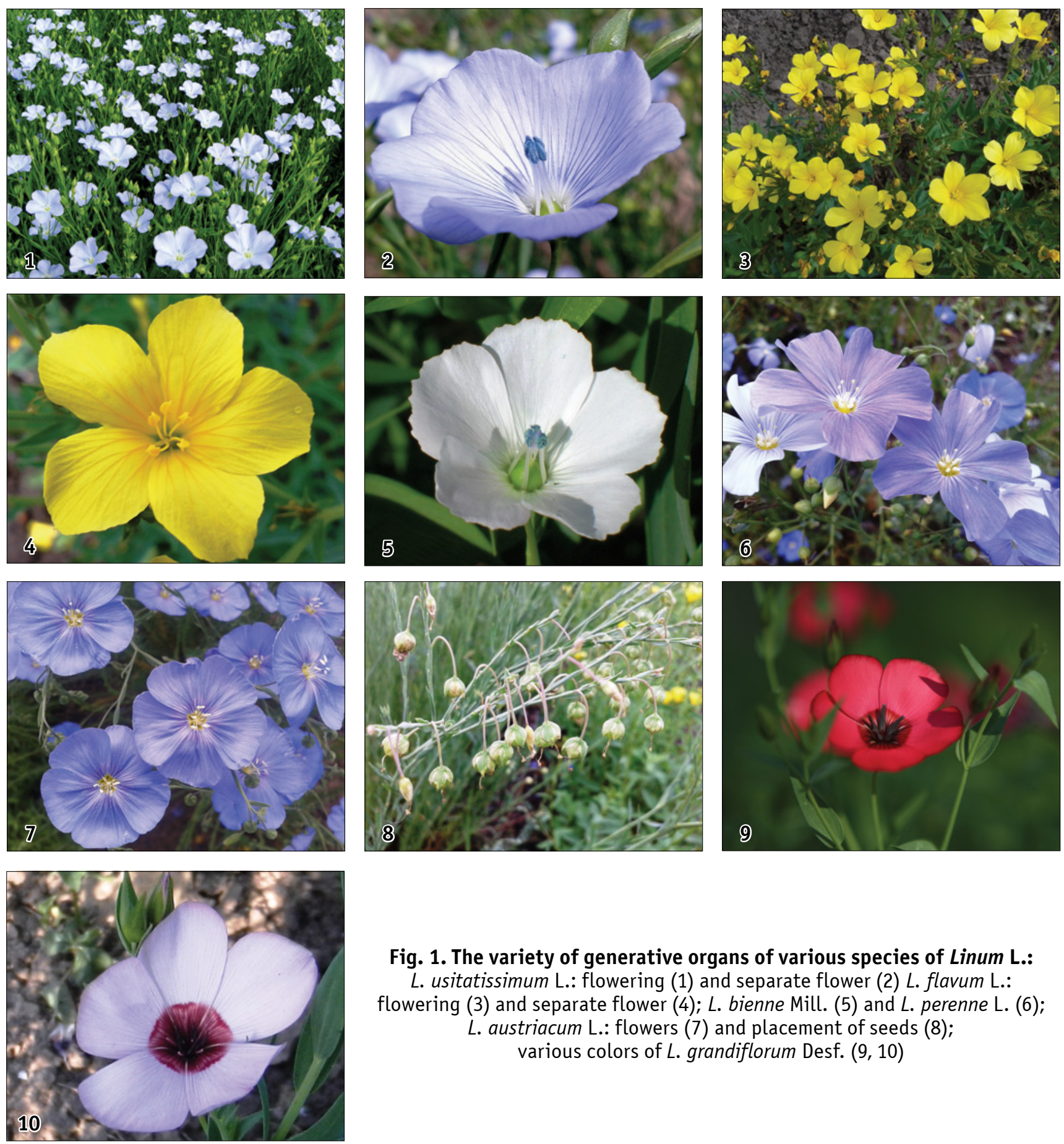

Fig. 1. The variety of generative organs of various species of Linum L.: L. usitatissimum L.: flowering (1) and separate flower (2) L. flavum L.: flowering (3) and separate flower (4); L. bienne Mill. (5) and L. perenne L. (6); L. austriacum L.: flowers (7) and placement of seeds (8); various colors of $L$. grandiflorum Desf. $(9,10)$

complex groups of vascular plants, so the views of researchers on its volume and the status of some taxa, as well as the diagnostic significance of morphological features are debatable [1]. In our work, we give the names of species according to the classification and version 1.1 of the "The Plant List" [21]. L. usitatissimum varieties grouping was done according to the modern widespread classification [22]; according to it, the species described earlier as independent, are combined into one polymorphic species with four varieties. Such a classification is most suitable for breeding, and the allocation of higher taxa does not make sense, since the morphotypes and ecotypes of modern flax varieties are very diverse [23].

It should be noted that L. usitatissimum being the most common in agricultural production and selection studies is mainly used in vitro culture. In our work we investigated various species of the genus Linum, which had distinctive features when cultivated in the indicated artificial conditions and at the same time could give new ideas not only about the biological diversity of the genus Linum, but also expanded the scope of its 
use in human practice, which determined the relevance of the research in this direction.

The purpose of the research is to determine the frequency and intensity of callus formation and organogenesis, the efficiency of microclonal reproduction of different species of the genus Linum L.

\section{Materials and methods}

Samples from the collection of genetic resources of the Institute of Bast Crops of the National Academy of Agrarian Sciences of Ukraine, including 11 species of the genus $\mathrm{Li}$ num L.: L. usitatissimum L., L. tenue Desf. (UF0401804, USA), L. bienne Mill. (UF0401805, USA), L. corymbulosum Pchb. (UF0401806, USA), L. nervosum Waldst. \& Kit. (UF0401807, USA), L. flavum L. (UF0402168, Germany), L. campanulatum L. (UF0402172, Germany), L. perenne L. (Ukraine), L. austriacum L. (UF0402192, Ukraine), L. grandiflorum Desf. (UF0401580, Germany), L. strictum L. (UF0401841, Portugal) were the object of the study. The species L. usitatissimum was represented by two varieties and two samples of each of them, namely: L. usitatissimum L. convar. elongatum - 'Glinum' (UF0401603, Ukraine), 'Krom' (UF0401494, Russia), L. usitatissimum L. convar. usitatissimum - 'Ruta' (UF0402228, Lithuania), 'Opus' (UF0402142, Belarus).

The seeds were sterilized with a $3 \%$ aqueous solution of sodium hypochlorite $(\mathrm{NaOCl})$ with 12.5-15 minutes of exposure, washed three times with sterile distilled water. Seeds of each species were germinated on agarized hormonefree nutrient medium Murashige and Skoog with $10 \mathrm{~g} / \mathrm{l}$ sucrose. On days 7-15 hypocotyls segments of seedlings 2-3 mm long were cultivated in biological test tubes $2 \mathrm{~cm}$ in diameter on Murashige and Skoog medium, supplemented with $0.05 \mathrm{mg} / \mathrm{l} \mathrm{NAA}$ and $1.0 \mathrm{mg} / \mathrm{l} \mathrm{BAP,}$ $30 \mathrm{~g} / \mathrm{l}$ sucrose, with 16 hours photoperiod (2500 flux) at $22-24{ }^{\circ} \mathrm{C}$, relative humidity of $60-80 \%$, to induce calus formation and organogenesis.

To obtain regenerated plants, such nutrient media were used: I - Murashige and Skoog [24], supplemented with $12.5 \mathrm{~g} / \mathrm{l}$ sucrose; II - Murashige and Skoog, supplemented with $12.5 \mathrm{~g} / \mathrm{l}$ glucose; III - Murashige and Skoog modified, containing 1/2 macro-, 2/1 micro-salts and vitamins, $0.3 \mathrm{mg} / \mathrm{l} \mathrm{IAA,} 10.0 \mathrm{~g} / \mathrm{l}$ sucrose ; IV White (1943), supplemented with $12.5 \mathrm{~g} / \mathrm{l}$ sucrose; V - Gamborg and Eveleigh [25], supplemented with $12.5 \mathrm{~g} / \mathrm{l}$ sucrose; VI and - Gamborg and Eveleigh, supplemented with $12.5 \mathrm{~g} / \mathrm{l}$ of glucose. Microclonal propagation of regenerated plants was performed when they reached a height of about $10 \mathrm{~cm}$.

Registrations were carried out on the 35 th day of cultivation in terms of the frequency of callus formation (the percentage of explants on which callus was formed), the mass of callus from one explant, the frequency of organogenesis (the percentage of calluses on which shoots were formed), the number of shoots that formed (excluding meristematic zones and embryonic shoots), and the height of normally developed shoots. A sampling was at least 30 explants and observations for each flax species and medium variant. The arithmetic mean, the error of the sample mean, and the least significant difference between the variants of experiment (LSD) were determined. Microclones for the height of shoots and the frequency of rhizogenesis were ranked in descending order.

\section{Results and discussion}

Various species of the genus Linum L. proved to be very sensitive to in vitro culture. The vast majority of them in $100 \%$ of cases formed a callus on the hypocotyl segments under the condition of cultivation on the Murashige and Skoog medium supplemented with $30 \mathrm{~g} / 1$ sucrose, $0.05 \mathrm{mg} / \mathrm{l} \mathrm{NAA}$ and $1.0 \mathrm{mg} / \mathrm{l} \mathrm{BAP}$, with 16 hours photoperiod ( 2500 flux) at $22-24{ }^{\circ} \mathrm{C}$, relative humidity of $60-80 \%$. The only exceptions were $L$. campanulatum (the frequency of callus formation - 81.25\%) and L. grandiflorum $(90.62 \%)$. At the same time, the intensity of callus formation in different species was uneven. On average, the mass of callus from the explants varied from $0.21 \pm 0.032(L$. gran diflorum) to $1.64 \pm 0.069 \mathrm{~g}$ (L. tenue).

The frequency of organogenesis, which ranged from 12.50 (L. campanulatum) to $100 \%$ (L. tenue and L. flavum), did not depend on the intensity of callus formation. On hypocotyl segments of L. grandiflorum, the callus was hardly formed (on average, only $0.21 \mathrm{~g}$ from explants), but shoots were formed with a very significant frequency $(96.88 \%)$ and height $(2.12 \mathrm{~cm})$. The sign of the frequency of organogenesis had a significant range of variation (the difference between the maximum and minimum values) at the level of $87.5 \%$, which indicates significant genotypic differences in the ability to form shoots from the undifferentiated group of cells in vitro in the presence of the aforementioned growth regulators or the possibility of initiating organogenesis as long as other phytohormones or their concentrations were added. Such an indicator as the number of shoots formed from a callus of one 
hypocotyl explant also varied depending on the studied species - from $1.8 \pm 0.25$ (L. grandiflorum) to $7.6 \pm 0.28 \mathrm{pcs}$. (L. perenne), that was more than four times. The height of the shoots and their habitus on the 35th day of cultivation in different species, as well as in natural conditions, also differed significantly (Fig. 2), namely, the limits of variation ranged from $0.82 \pm 0.067$ ( $L$. nervosum) to $2.12 \pm 0.351 \mathrm{~cm}$ ( $L$. grandiflorum). The relationship between such traits as the number of shoots and their height was not observed (Table 1).

Microclonal propagation of the obtained regenerating plants (Fig. 2) showed differences in the reaction of different species of the ge- nus Linum L. to the composition of the nutrient medium. Similarly to the natural conditions, according to the average data on all nutrient media, shoots were high in L. strictum, L. tenue, L. usitatissimum convar. usitatissimum and L. corymbulosum (grades 1-4); L. bienne, L. nervosum, L. usitatissimum convar. elongatum and L. campanulatum (grades 5-8) had had an average height; L. flavum, L. perenne, L. grandiflorum and L. austriacum (ranks 9-12) belonged to low-growing plants. The height of the shoots varied from 1.89 to $12.52 \mathrm{~cm}$.

According to the average data for 12 species and varieties, shoots grew intensively on the
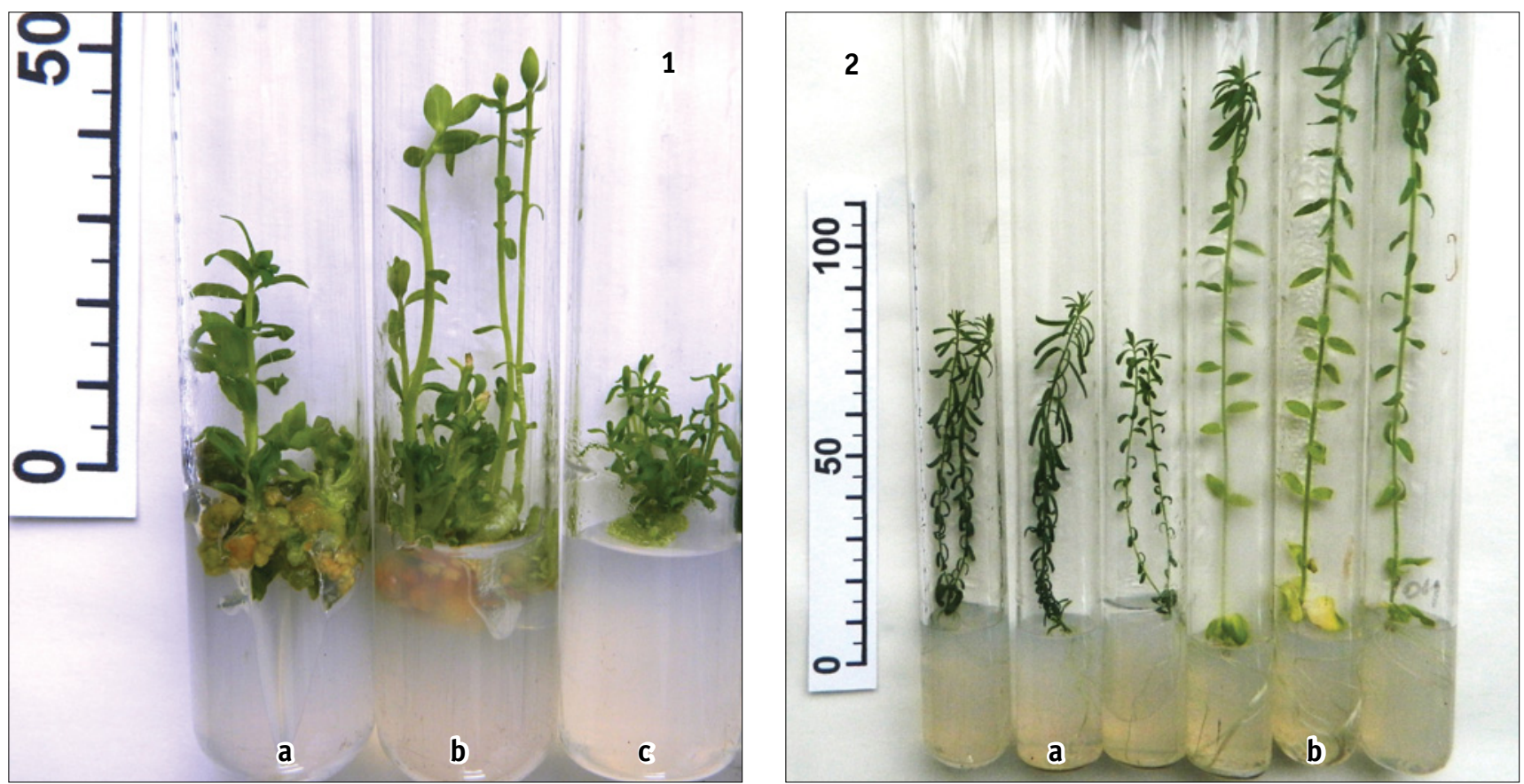

Fig. 2. Regeneration of shoots from callus and microclones of various species of the genus Linum L.: 1 - L. usitatissimum convar. usitatissimum (a), L. strictum (b) and L. perenne (c); 2 - L. perenne (a), L. usitatissimum convar. elongatum (b)

Table 1

The ability to callus formation and organogenesis in vitro in different species of the genus Linum L.

\begin{tabular}{|l|c|c|c|c|c|}
\hline \multirow{2}{*}{ Species } & \multicolumn{2}{|c|}{ Intensity of callus formation } & \multicolumn{3}{c|}{ Intensity of organogenesis } \\
\cline { 2 - 6 } & $\begin{array}{c}\text { Frequency of } \\
\text { calus formation, } \\
\%\end{array}$ & $\begin{array}{c}\text { Mass of a callus } \\
\text { from explant, } \\
\text { g }\end{array}$ & $\begin{array}{c}\text { Frequency } \\
\text { of organogenesis, } \\
\%\end{array}$ & $\begin{array}{c}\text { Number } \\
\text { of shoots, } \\
\text { pcs }\end{array}$ & $\begin{array}{c}\text { Hight of shoots, } \\
\text { cm }\end{array}$ \\
\hline L. usitatissimum convar. elongatum & 100 & $1.14 \pm 0.092$ & 90.62 & $3.0 \pm 0.24$ & $1.00 \pm 0.062$ \\
L. usitatissimum convar. usitatissimum & 100 & $0.87 \pm 0.080$ & 58.22 & $2.2 \pm 0.36$ & $1.15 \pm 0.062$ \\
L. tenue & 100 & $1.64 \pm 0.069$ & 100 & $2.6 \pm 0.14$ & $1.62 \pm 0.238$ \\
L. bienne & 100 & $1.10 \pm 0.091$ & 93.75 & $2.8 \pm 0.13$ & $1.28 \pm 0.091$ \\
L. corymbulosum & 100 & $0.48 \pm 0.068$ & 65.62 & $2.2 \pm 0.13$ & $0.83 \pm 0.076$ \\
L. nervosum & 100 & $0.73 \pm 0.075$ & 50.00 & $2.0 \pm 0.07$ & $0.82 \pm 0.067$ \\
L. flavum & 100 & $0.40 \pm 0.050$ & 100 & $3.8 \pm 0.24$ & $0.90 \pm 0.071$ \\
L. campanulatum & 81.25 & $0.42 \pm 0.046$ & 12.50 & $3.7 \pm 0.22$ & $1.04 \pm 0.078$ \\
L. perenne & 100 & $0.60 \pm 0.058$ & 53.33 & $7.6 \pm 0.28$ & $1.76 \pm 0.158$ \\
L. austriacum & 100 & $0.54 \pm 0.029$ & 93.75 & $2.0 \pm 0.08$ & $1.54 \pm 0.175$ \\
L. grandiflorum & 90.62 & $0.21 \pm 0.032$ & 96.88 & $1.8 \pm 0.25$ & $2.12 \pm 0.351$ \\
L. strictum & 100 & $0.94 \pm 0.105$ & 87.50 & $2.6 \pm 0.41$ & $1.51 \pm 0.243$ \\
\hline
\end{tabular}




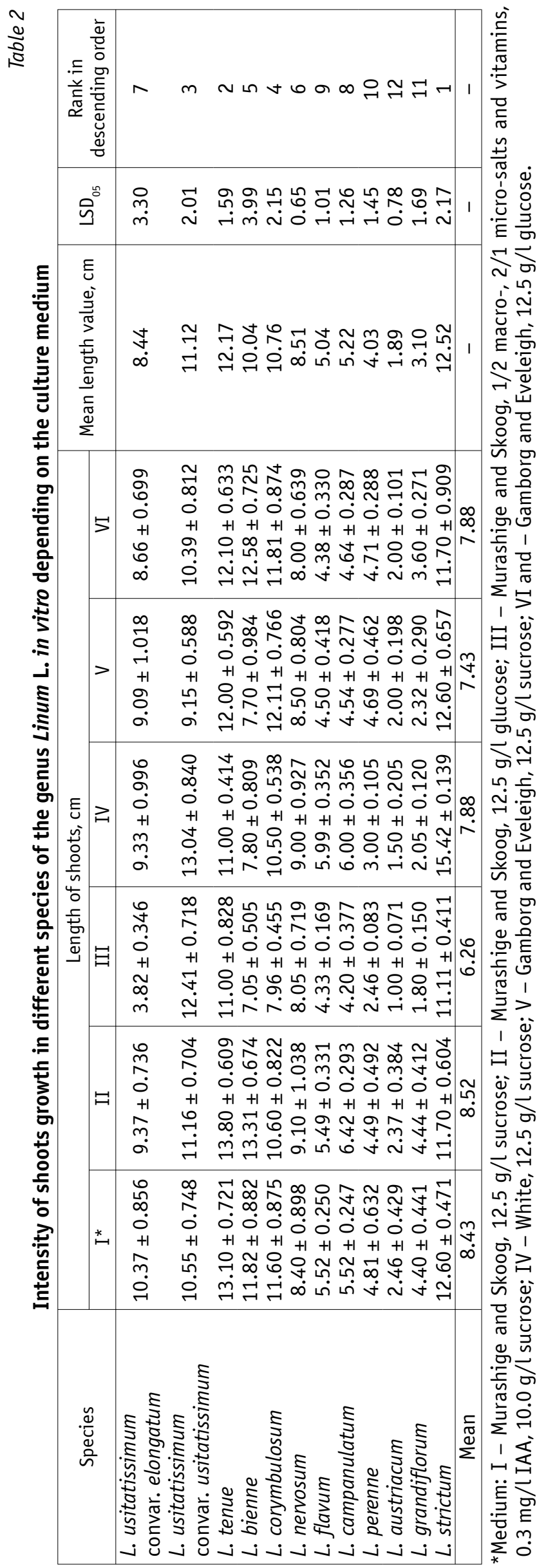

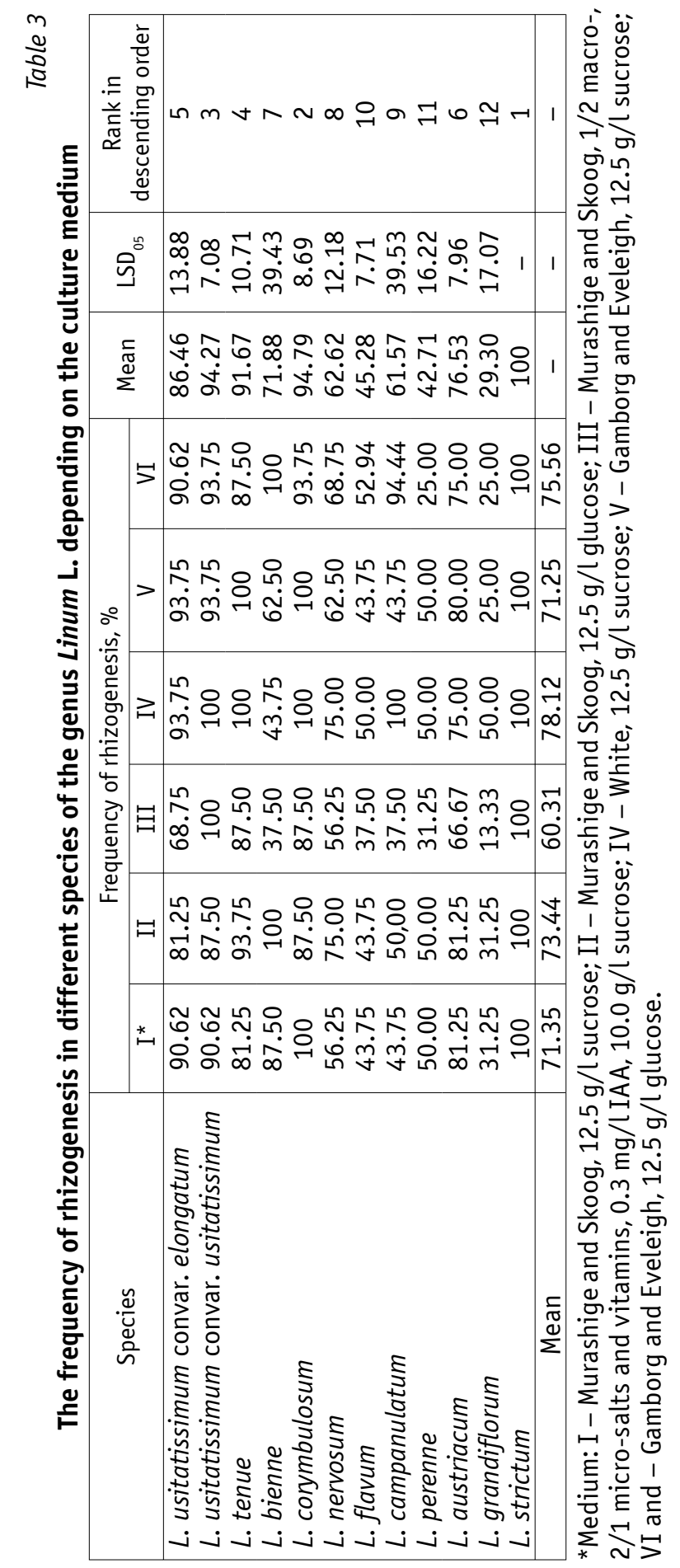


Murashige and Skoog medium $(8.43 \mathrm{~cm}$ in the variant with the addition of $12.5 \mathrm{~g} / \mathrm{l}$ sucrose and $8.52 \mathrm{~cm}$ with the addition of $12.5 \mathrm{~g} / \mathrm{l}$ glucose). Somewhat less, the height of microclones appeared on White's medium with the addition of $12.5 \mathrm{~g} / \mathrm{l}$ sucrose and Gamborg and Eveleigh medium containing $12.5 \mathrm{~g} / \mathrm{l}$ glucose $(7.88 \mathrm{~cm}$ each). An increase in height was observed on White's medium, but the leaves and lateral meristems died at $2 / 3$ of the lower part of the shoot, what made further microclonal reproduction impossible. The modified Murashige and Skooga medium with half the dose of macrosalts, a double dose of micro salts and vitamins, $0.3 \mathrm{mg} / \mathrm{l} \mathrm{IAA}, 10.0 \mathrm{~g} / \mathrm{l}$ sucrose was ineffective.

A particular composition of the medium on a particular type of flax may affect differently. For example, in L. usitatissimum convar. elongatum abrupt growth suppression was observed on the modified Murashige and Skoog medium with half a dose of macro salts, a double dose of micro salts and vitamins, $0.3 \mathrm{mg} / \mathrm{l}$ IAA and $10.0 \mathrm{~g} / \mathrm{l}$ sucrose, and shoots of L. usitatissimum convar. usitatissimum were the highest when cultivated on this medium (Table 2).

Like the trait of height, rhizogenesis in different species of the studied genus occured with unequal intensity. According to the average data, the microclones of L. strictum, L. corymbulosum, L. usitatissimum convar usitatissimum and L. tenue (ranks 1-4) had the highest frequency of rhizogenesis. The average frequency of normal developed roots was in L. usitatissimum convar. elongatum, L. austriacum, L. bien$n e$ and L. nervosum (ranks 5-8), the lowest incidence of rhizogenesis was observed in L. campanulatum, L. flavum, L. perenne and L. grandiflorum (ranks 9-12). The average frequency of rhizogenesis was in the range of 29.30$100 \%$.

Most often microclones formed roots on White's medium with $12.5 \mathrm{~g} / \mathrm{l}$ sucrose $(78.12 \%)$, which was quite predictable, positive results were obtained on Murashige and Skoog, Gamborg and Eveleigh media (from 71.25 to $75.56 \%$ ). At the same time, glucose, as a source of carbohydrates in the medium and osmotic pressure in the cells, to a certain extent increased the intensity of rhizogenesis. The modified medium, although it contained auxin IAA, turned out to be less suitable for the induction of rooting in regenerated flax shoots (Table 3).

Just as within one species of L. usitatissimum, callus tissue formation, regeneration, growth, development and rooting of shoots in vitro depends on the genotype (starting material) [2, $12-14,16,19,20]$, and within the whole genus, there are significant differences in the course of these phenomena. In general, according to the intensity of callus formation (by a complex of characters), the following species were distinguished: L. usitatissimum convar. elongatum, $L$. tenue, L. bienne and L. strictum. The most intensive organogenesis (by the complex of characters) is inherent in the species: L. tenue, L. bienne, L. flavum, L. austriacum and L. grandiflorum. The efficacy of obtaining somaclones in vitro under the described cultivation conditions was rather low in $L$. nervosum and $L$. campanulatum (the frequency of organogenesis was 50.00 and $12.50 \%$, respectively). Despite the fact that the combination of NAA and BAP is most often described as optimal for flax calus formation and organogenesis $[2,13]$, in less sensitive species to culture in vitro and these growth regulators of exogenous origin, the possibilities of increasing the production of regenerative plants in the event of a change, for example, of the phytohormonal composition of the medium remain open.

In general, for microclonal propagation of species of the genus Linum, the Murashige and Skoog, Gamborg and Eveleigh media with the addition of $12.5 \mathrm{~g} / \mathrm{l}$ glucose were optimal. At the final stages of microclonal propagation, before transferring microclones in vivo, it is advisable to use the White medium, which contributes to a high frequency of rhizogenesis. For each species, among the studied media and modifications by the complex of features, it is possible to select the optimal ones - those that contribute to the intensive growth and development of the shoots, and those on which active rhizogenesis is observed (Table 4).

Optimum media for microclonal propagation of species of the genus Linum L.

Table 4

\begin{tabular}{|l|l|l|l|}
\hline \multicolumn{3}{|c|}{ Medium } \\
\hline Murashige and Skoog & \multicolumn{1}{|c|}{ Murashige and Skoog (modified) } & \multicolumn{1}{c|}{ White } & Gamborg and Eveleigh \\
\hline $\begin{array}{l}\text { L. bienne, } \\
\text { L. nervosum, }\end{array}$ & L. usitatissimum & L. usitatissimum & L. bienne, \\
L. perenne, & convar. usitatissimum & convar. usitatissimum, & L. corymbulosum, \\
L. austriacum, & & L. nervosum, & L. strictum \\
L. grandiflorum, & & L. flavum, \\
L. strictum & & L. campanulatum, & \\
& L. strictum & \\
\hline
\end{tabular}


Different varieties of $L$. usitatissimum - fiber flax and oilseeds - have distinctive tendencies in the intensity of callus formation, organogenesis, and the growth of microclones, which must be taken into account in agricultural biotechnology and when used in breeding programs.

It is practically impossible to choose a universal nutrient medium for effective callus formation and organogenesis and microclonal propagation of different plants in vitro, even if they belong to the same genus. In vitro culture morphogenetic reactions may differ not only from the age and type of the explant selected in the study, but also from the studied variety or sample of the same species, therefore, very often, researchers have to select for each studied variety (genotype) separately and appropriate growth regulators (concentration (s) of phytohormone (s) and/or their ratio) for the effective induction of somatic organogenesis (shootand-root formation) or embryogenesis in vitro.

\section{Conclusions}

Various species of the genus Linum L., with a few exceptions, are largely capable of forming callus and regenerating shoots in vitro when cultivated at $22-24{ }^{\circ} \mathrm{C}$, relative humidity of $60-80 \%$, with 16 hours photoperiod (2500 flux) on agar nutrient Murashige and Skoog medium, supplemented with $0.05 \mathrm{mg} / \mathrm{l} \mathrm{NAA}, 1.0 \mathrm{mg} / \mathrm{l}$ BAP. The frequency, intensity of callus formation and organogenesis, the effectiveness of microclonal reproduction depended on the genotype of a particular species, therefore for each of them it is advisable to select separately the composition of the nutrient medium and growth regulators. The frequency of callus formation of the studied samples on the 35th day of cultivation varied within $81.25-100 \%$, the mass of a callus from one explant $-0.21-1.64 \mathrm{~g}$, the frequency of organogenesis $-12.50-100 \%$, the number of shoots $-1.8-7.6 \mathrm{pcs}$. and the height of the shoots is $0.82-2.12 \mathrm{~cm}$. The following species L. usitatissimum convar. elongatum, L. tenue, L. bienne and L. strictum were distinguished by the high intensity of callus formation. Intensive organogenesis characteristic of the species L. tenue, L. bienne, L. flavum, L. aust riacum and $L$. grandiflorum. The effectiveness of shoots growth was quite low in $L$. nervosum and L. campanulatum. In total, for the microclonal reproduction of species of the genus $\mathrm{Li}$ num L., Murashige and Skoog, Gamborg and Eveleigh are optimal with the addition of $12.5 \mathrm{~g} / \mathrm{l}$ of glucose. At the final stages of microclonal propagation, before transferring microclones in vivo, it is advisable to use the White medium, which contributes to a high frequency of rhizogenesis. Varieties of L. usitatissimum convar. elongatum and convar. usitatissimum had different responses to in vitro culture.

\section{References}

1. Optasiuk, 0. M., \& Shevera, M. V. (2011). Rid Linum L. u flori Ukrainy [The genus Linum L. in the flora of Ukraine]. Kyiv: Alterpres. [in Ukrainian]

2. Shisha, E. N., Emets, A. I., Guzenko, E. V., Lemesh, V. A., Kartel', N. A., \& Blyum, Ya. B. (2011). Study of the regeneration capability and root formation in Ukrainian and Belarusian flax cultivars. Fiziol. Biokhim. Kul't. Rast. [Physiology and Biochemistry of Cultivated Plants], 43(1), 57-64. [in Russian]

3. Janowicz, J., Niemann, J., \& Wojciechowski, A. (2012). The effect of growth regulators on the regeneration ability of flax (Linum usitatissimum L.) hypocotyl explants in in vitro culture. BioTechnologia, 93(2), 135-138. doi: 10.5114/bta.2012.46578

4. Siegień, I., Adamczuk, A., \& Wróblewska, K. (2013). Light affects in vitro organogenesis of Linum usitatissimum $\mathrm{L}$. and its cyanogenic potential. Acta Physiol. Plant., 35(3), 781-789. doi: 10.1007/s11738-012-1118-4

5. Mundhara, R., \& Rashid, A. (2006). TDZ-induced triple-response and shoot formation on intact seedlings of Linum, putative role of ethylene in regeneration. Plant Sci., 170(2), 185-190. doi: $10.1016 / j$.plantsci.2005.06.015

6. Seta-Koselska, A., \& Skórzyńska-Polit, E. (2017). Optimization of in vitro culture conditions for obtaining flax (Linum usitatissimum L. cv. Modran) cell suspension culture. BioTechnologia, 98(3), 183-188. doi: 10.5114/bta.2017.70796

7. Tsygankova, V. A., Bayer, 0. 0., Andrusevich, Ya. V., Galkin, A. P., Brovarets, V. S., Yemets, A. I., \& Blume, Ya. B. (2016). Screening of five and six-membered nitrogen-containing heterocyclic compounds as new effective stimulants of Linum usitatissimum $\mathrm{L}$. organogenesis in vitro. Int. J. Med. Biotechnol. Genetics, S2:001, 1-9. doi: 10.19070/2379-1020-SI02001

8. Yildiz, M., \& Özgen, M. (2004). The effect of a submersion pretreatment on in vitro explant growth and shoot regeneration from hypocotyls of flax (Linum usitatissimum). Plant Cell Tiss. Organ. Cult., 77(1), 111-115. doi: 10.1023/B:TICU.0000016493.03592.c3

9. Yildiz, M., Sağlik, C., Telci, C., \& Erkilich, E. G. (2011). The effect of in vitro competition on shoot regeneration from hypocotyl explants of Linum usitatissimum. Turk. J. Bot., 35(2), 211-218. doi: 10.3906/bot-1005-26

10. Beyaz, R., \& Yildiz, M. (2019). The effect of inter-plantal competition on in vitro seed germination and seedling growth in flax (Linum usitatissimum L.). Eskişehir Technical Univ. J. of Sci. and Tech. C-Life Sci. and Biotech., 8(1), 61-68. doi: 10.18036/ aubtdc.427128

11. Rutkowska-Krause, I., Mankowska, G., Lukaszewicz, M., \& Szopa, J. (2003). Regeneration of flax (Linum usitatissimum L.) plants from anther culture and somatic tissue with increased resistance to Fusarium oxysporum. Plant Cell Rep., 22(2), 110116. doi: 10.1007/s00299-003-0662-1

12. Burbulis, N., Blinstrubienè, A., Sliesaravičius, A., \& Venskutonienè, E. (2005). Influence of genotype, growth regulators, sucrose level and preconditioning of donor plants on flax (Linum usitatissimum L.) anther culture. Acta Biol. Hung., 56(3-4), 323-331. doi: 10.1556/ABiol.56.2005.3-4.15

13. Burbulis, N., \& Blinstrubienè, A. (2011). Genotypic and exogenous factors affecting linseed (Linum usitatissimum L.) anther culture. J. Food Agricult. Environ., 9(3-4), 364-367. doi: 10.1234/4.2011.2285

14. Burbulis, N., Blinstrubienè, A., Masienè, R., \& Jonytiene, V. (2012). Influence of genotype, growth regulators and sucrose concentration on linseed (Linum usitatissimum L.) anther culture. J. Food Agricult. Environ., 10(3-4), 764-767. doi: 10.1234/4.2012.3509 
15. Millam, S., Davidson, D., \& Powell, W. (1992). The use of flax (Linum usitatissimum) as a model system for studies on organogenesis in vitro: the effect of different carbohydrates. Plant Cell Tiss. Organ Cult., 28(2), 163-166. doi: 10.1007/BF00055512

16. Chen, Y., \& Dribnenki, P. (2002). Effect of genotype and medium composition on flax Linum usitatissimum L. anther culture. Plant Cell Rep., 21(3), 204-207. doi: 10.1007/s00299-002-0500-x

17. Soroka, A. I. (2010). Peculiarities of donor plant preparation and flax anther cultivation in vitro for haploid plant production. Visnik Zaporiz'kogo nacional'nogo universitetu. Biologični nauki [Visnyk of Zaporizhzhya National University. Biological Sciences], 2, 13-19. [in Russian]

18. Sakhare, S. P., \& Mendhulkar, V. D. (2016). Embryo excised callus induction and rhizogenesis in Linum usitatissimum L. Int. J. Pharm. Bio. Sci., 7(3), 507-511.

19. Blinstrubienè, A., Burbulis, N., \& Masienè, R. (2017). Genotypic and exogenous factors affecting linseed ovary culture. Zemdirbyste-Agriculture, 104(3), 243-248. doi: 10.13080/ z-a.2017.104.031

20. Bonell, M., \& Lassaga, S. L. (2002). Genetic analysis of the response of linseed (Linum usitatissimum L.) somatic tissue to in vitro cultivation. Euphytica, 125(3), 367-372. doi: 10.1023/A:1016013609068

21. The Plant List. (n.d.). Retrieved from http://www.theplantlist.org

22. Diederrichsen, A., \& Richards, K. (2003). Cultivated flax and the genus Linum L.: Taxonomy and germplasm conservation. In A. D. Muir, \& N. D. Westcott (Eds.), Flax: The genus Linum (pp. 39-42). Boca Raton: CRC Press.

23. Zelentsov, S. V., Zelentsov, V. S., Moshnenko, E. V., \& Ryabenko, L. G. (2016). Modern understanding of the phylogeny and taxonomy of genus Linum L. and flax (Linum usitatissimum L.). Maslichnye kul'tury. Nauchno-tekhnicheskiy byulleten' VNIIMK [0il Crops. Scientific and technical bulletin of All-Russia Research Institute of Oil Crops], 1, 106-121. [in Russian]

24. Murashige, T., \& Skoog, F. (1962). A revised medium for rapid growth and bio assays with tobacco tissue cultures. Physiol. Plant., 15(3), 473-497. doi: 10.1111/j.1399-3054.1962.tb08052.x

25. Gamborg, 0. L., \& Eveleigh, D. E. (1968). Culture methods and detection of glucanases in suspension cultures of wheat and barley. Can. J. Biochem. Cell B., 46(5), 417-421. doi: 10.1139/ 068-063

\section{Використана література}

1. Оптасюк 0. М., Шевера М. В. Рід Linum L. у флорі України. Київ : Альтерпрес, 2011. 276 с.

2. Шиша Е. Н., Емец А. И., Гузенко Е. В. и др. Изучение регенерационной способности и корнеобразования у сортов льнадолгунца украинской и белорусской селекции. Физиология и биохимия культ. растений. 2011. Т. 43, № 1. С. 57-64.

3. Janowicz J., Niemann J., Wojciechowski A. The effect of growth regulators on the regeneration ability of flax (Linum usitatissimum L.) hypocotyl explants in in vitro culture. BioTechnologia. 2012. Vol. 93, Iss. 2. P. 135-138. doi: 10.5114/ bta.2012.46578

4. Siegień I., Adamczuk A., Wróblewska K. Light affects in vitro organogenesis of Linum usitatissimum L. and its cyanogenic potential. Acta Physiol. Plant. 2013. Vol. 35, Iss. 3. P. 781-789. doi: 10.1007/s11738-012-1118-4

5. Mundhara R., Rashid A. TDZ-induced triple-response and shoot formation on intact seedlings of Linum, putative role of ethylene in regeneration. Plant Sci. 2006. Vol. 170, Iss. 2. P. 185-190. doi: 10.1016/j.plantsci.2005.06.015

6. Seta-Koselska A., Skórzyńska-Polit E. Optimization of in vitro culture conditions for obtaining flax (Linum usitatissimum L. cv. Modran) cell suspension culture. BioTechnologia. 2017. Vol. 98, Iss. 3. P. 183-188. doi: 10.5114/bta.2017.70796

7. Tsygankova V. A., Bayer 0. 0., Andrusevich Ya. V. et al. Screening of five and six-membered nitrogen-containing heterocyclic compounds as new effective stimulants of Linum usitatissi- mum L. organogenesis in vitro. Int. J. Med. Biotechnol. Genetics. 2016. S2:001. P. 1-9. doi: 10.19070/2379-1020-SI02001

8. Yildiz M., Özgen M. The effect of a submersion pretreatment on in vitro explant growth and shoot regeneration from hypocotyls of flax (Linum usitatissimum). Plant Cell Tiss. Organ. Cult. 2004. Vol. 77, Iss. 1. P. 111-115. doi: 10.1023/B:TICU.0000016493. 03592.c3

9. Yildiz M., Sağlik C., Telci C., Erkilich E. G. The effect of in vitro competition on shoot regeneration from hypocotyl explants of Linum usitatissimum. Turk. J. Bot. 2011. Vol. 35, Iss. 2. P. $211-$ 218. doi: 10.3906/bot-1005-26

10. Beyaz R., Yildiz M. The effect of inter-plantal competition on in vitro seed germination and seedling growth in flax (Linum usitatissimum L.). Eskişehir Technical Univ. J. of Sci. and Tech. C - Life Sci. and Biotech. 2019. Vol. 8, Iss. 1. P. 61-68. doi: $10.18036 /$ aubtdc. 427128

11. Rutkowska-Krause I., Mankowska G., Lukaszewicz M., Szopa J. Regeneration of flax (Linum usitatissimum L.) plants from anther culture and somatic tissue with increased resistance to Fusarium oxysporum. Plant Cell Rep. 2003. Vol. 22, Iss. 2. P. 110-116. doi: 10.1007/s00299-003-0662-1

12. Burbulis N., Blinstrubienè A., Sliesaravičius A., Venskutonienè E. Influence of genotype, growth regulators, sucrose level and preconditioning of donor plants on flax (Linum usitatissimum L.) anther culture. Acta Biol. Hung. 2005. Vol. 56, Iss. 3-4. P. 323-331. doi: 10.1556/ABiol.56.2005.3-4.15

13. Burbulis N., Blinstrubienè A. Genotypic and exogenous factors affecting linseed (Linum usitatissimum L.) anther culture. J. Food Agricult. Environ. 2011. Vol. 9, Iss. 3-4. P. 364-367. doi: 10.1234/4.2011.2285

14. Burbulis N., Blinstrubienè A., Masienè R., Jonytienè V. Influence of genotype, growth regulators and sucrose concentration on linseed (Linum usitatissimum L.) anther culture. J. Food Agricult. Environ. 2012. Vol. 10, Iss. 3-4. P. 764-767. doi: 10.1234/4.2012.3509

15. Millam S., Davidson D., Powell W. The use of flax (Linum usitatissimum) as a model system for studies on organogenesis in vitro: the effect of different carbohydrates. Plant Cell Tiss. Organ. Cult. 1992. Vol. 28, Iss. 2. P. 163-166. doi: 10.1007/ BF00055512

16. Chen Y., Dribnenki P. Effect of genotype and medium composition on flax Linum usitatissimum L. anther culture. Plant Cell Rep. 2002. Vol. 21, Iss. 3. P. 204-207. doi: 10.1007/s00299002-0500-x

17. Сорока А. И. Особенности подготовки материала и культивирования in vitro пыльников льна при получении гаплоидных растений. Вісн. Запорізького нац. ун-ту. Біологічні науки. 2010. № 2. C. 13-19.

18. Sakhare S. P., Mendhulkar V. D. Embryo excised callus induction and rhizogenesis in Linum usitatissimum L. Int. J. Pharm. Bio. Sci. 2016. Vol. 7, Iss. 3. P. 507-511.

19. Blinstrubienè A., Burbulis N., Masienè R. Genotypic and exogenous factors affecting linseed ovary culture. ZemdirbysteAgriculture. 2017. Vol. 104, No. 3. P. 243-248. doi: 10.13080/ z-a.2017.104.031

20. Bonell M., Lassaga S. L. Genetic analysis of the response of linseed (Linum usitatissimum L.) somatic tissue to in vitro cultivation. Euphytica. 2002. Vol. 125, Iss. 3. P. 367-372. doi: 10.1023/A:1016013609068

21. The Plant List. URL: http://www.theplantlist.org

22. Diederrichsen A., Richards K. Cultivated flax and the genus $\mathrm{Li}$ num L.: Taxonomy and germplasm conservation. Flax: The genus Linum / A. D. Muir, N. D. Westcott (Eds.). Boca Raton : CRC Press, 2003. P. 39-42.

23. Зеленцов С. В., Зеленцов В. С., Мошненко Е. В., Рябенко Л. Г. Современные представления о филогенезе и таксономии рода Linum L. и льна обыкновенного (Linum usitatissimum L.). Масличные культуры. Науч.-техн. бюл. ВНИИ масличных культур. 2016. Вып. 1. С. 106-121. 
24. Murashige T., Skoog F. A revised medium for rapid growth and bio assays with tobacco tissue cultures. Physiol. Plant. 1962. Vol. 15, Iss. 3. P. 473-497. doi: 10.1111/j.1399-3054.1962.tb08052.x
25. Gamborg 0. L., Eveleigh D. E. Culture methods and detection of glucanases in suspension cultures of wheat and barley. Can. J. Biochem. Cell B. 1968. Vol. 46, Iss. 5. P. 417-421. doi: $10.1139 / 068-063$

\section{УДК 633.521:58.085}

Міщенко С. В. ${ }^{*}$, Кривошеєва Л. М. Калусогенез, органогенез і мікроклональне розмноження in vitro різних видів роду Linum L. Plant Varieties Studying and Protection. 2019. Т. 15, № 2. С. 124-134. https://doi.org/10.21498/2518-1017.15.2.2019.173558

Інститут луб'яних культур НААН України, вул. Терещенків, 45, м. Глухів, Сумська обл., 41400, Україна, *e-mail: serhii-mishchenko@ukr.net

Мета. Установити частоту та інтенсивність калусо- й органогенезу, ефективність мікроклонального розмноження різних видів роду Linum L. (Linaceae) в умовах in vitro. Методи. Для індукування калусо- й органогенезу в умовах in vitro гіпокотильні сегменти видів Linum usitatissimum L. convar. elongatum $\mathrm{i}$ convar. usitatissimum, L. tenue Desf., L. bienne Mill., L. corymbulosum Pchb., L. nervosum Waldst. \& Kit., L. flavum L., L. campanulatum L., $L$. perenne L., L. austriacum L., L. grandiflorum Desf., L. strictum L. культивували на середовищі Мурасіге і Скуга 3 додаванням 0,05 мг/л 1-нафтилоцтової кислоти та 1,0 мг/л 6-бензиламінопурину за 16-годинного фотоперіоду, інтенсивності освітлення 2500 лк, відносній вологості $60-80 \%$ i температурі повітря 22-24 ${ }^{\circ} \mathrm{C}$. Для мікроклонального розмноження використовували середовища Мурасіге і Скуга, Уайта, Гамборга і Евелега та їх модифікації. Результати вимірювань інтерпретували за середнім арифметичним, похибкою вибіркової середньої, найменшою істотною різницею та ранжирували. Результати. Різні види роду Linum значною мірою здатні до утворення калусу і регенерації пагонів за вказаних умов культивування. Частота калусогенезу для досліджуваних зразків на 35-ту добу культивування змінювалася в межах 81,25-100\%, маса калусу з одного експланта - 0,211,64 г, частота органогенезу - 12,50-100\%, кількість пагонів - 1,8-7,6 шт. і висота пагонів - 0,82-2,12 см.
За високою інтенсивністю калусоутворення виділилися такі види: L. usitatissimum convar. elongatum, L. tenue, L. bienne i L. strictum. Найінтенсивніший органогенез властивий видам L. tenue, L. bienne, L. flavum, L. austriacum і L. grandiflorum. Ефективність отримання сомаклонів була досить низькою в L. nervosum i L. campanulatum. Загалом для мікроклонального розмноження видів роду Linum оптимальними є середовища Мурасіге і Скуга, Гамборга і Евелега з додаванням 12,5 г/л глюкози. На завершальних етапах мікроклонального розмноження перед перенесенням мікроклонів in vivo доцільно використовувати середовище Уайта, яке сприяє високій частоті ризогенезу. Різновиди L. usitatissimum convar. elongatum i convar. usitatissimum мали різну реакцію на культивування в умовах in vitro. Висновки. Частота, інтенсивність калусо- й органогенезу, ефективність мікроклонального розмноження залежала від генотипу певного виду, тому для кожного з них доцільно окремо добирати склад поживного середовища і регулятори росту. Деякі види роду Linum ще не досліджені в умовах in vitro, тому отримані результати надалі дають змогу розширити сферу їх використання у практичній діяльності, зокрема в селекції як новий вихідний матеріал із сомаклональною мінливістю, у міжвидових схрещуваннях, у декоративному квітникарстві.

Ключові слова: Linum L.; in vitro; живильне середовище; фітогормони; пагін.

УДК 633.521:58.085

Мищенко С. В. ${ }^{*}$, Кривошеева Л. М. Каллусогенез, органогенез и микроклональное размножение in vitro разных видов рода Linum L. // Plant Varieties Studying and Protection. 2019. Т. 15, № 2. С. 124-134. https://doi.org/10.21498/2518-1017.15.2.2019.173558

Институт лубяных культур НААН Украины, ул. Терещенков, 45, г. Глухов, Сумская обл., 41400, Украина, *e-mail: serhii-mishchenko@ukr.net

Цель. Установить частоту и интенсивность каллусои органогенеза, эффективность микроклонального размножения различных видов рода Linum L. (Linaceae) в условиях in vitro. Методы. Для индуцирования каллусои органогенеза в условиях in vitro гипокотильные сегменты видов Linum usitatissimum L. (convar. elongatum и convar. usitatissimum), L. tenue Desf., L. bienne Mill., L. corymbulosum Pchb., L. nervosum Waldst. \& Kit., L. flavum L., L. campanulatum L., L. perenne L., L. austriacum L., L. grandiflorum Desf., L. strictum L. культивировали на среде Мурасиге и Скуга с добавлением 0,05 мг/л 1-нафтилуксусной кислоты и 1,0 мг/л 6-бензиламинопурина при 16-часовом фотопериоде, интенсивности освещения 2500 лк, относительной влажности 60-80\% и температуре воздуха $22-24{ }^{\circ} \mathrm{C}$. Для микроклонального размножения использовали среды
Мурасиге и Скуга, Уайта, Гамборга и Эвелега и их модификации. Результаты измерений интерпретировали по среднему арифметическому, погрешности выборочной средней, наименьшей существенной разнице и ранжировали. Результаты. Различные виды рода Linum в значительной мере способны к образованию каллуса и регенерации побегов в условиях in vitro при указанных условиях культивирования. Частота каллусогенеза для исследуемых образцов на 35-е сутки культивирования колебалась в пределах 81,25-100,00\%, масса каллуса с одного экспланта - 0,21-1,64 г, частота органогенеза - 12,50-100\%, количество побегов - 1,8-7,6 шт. и высота побегов - 0,82-2,12 см. По высокой интенсивности каллусообразования выделились следующие виды: L. usitatissimum convar. elongatum, L. tenue, L. bienne и L. strictum. Наиболее интенсивный органо- 
генез свойственный видам L. tenue, L. bienne, L. flavum, L. austriacum и L. grandiflorum. Эффективность получения сомаклонов была достаточно низкой у L. nervosum и L. campanulatum. В целом для микроклонального размножения видов рода Linum. оптимальными являются среды Мурасиге и Скуга, Гамборга и Эвелега с добавлением 12,5 г/л глюкозы. На завершающих этапах микроклонального размножения перед переносом микроклонов in vivo целесообразно использовать среду Уайта, которая способствует высокой частоте ризогенеза. Разновидности L. usitatissimum convar. elongatum и convar. usitatissimum имели разную реакцию на культивирование в условиях in vitro. Выводы. Частота, ин- тенсивность каллусо- и органогенеза, эффективность микроклонального размножения зависела от генотипа определенного вида, поэтому для каждого их них целесообразно отдельно подбирать состав питательной среды и регуляторы роста. Отдельные виды рода Linum не исследованы в условиях in vitro, поэтому полученные результаты дают возможность в дальнейшем расширить сферу их использования в практической деятельности, в частности в селекции как новый исходный материал с сомаклональной изменчивостью, в межвидовых скрещиваниях, в декоративном цветоводстве.

Ключевые слова: Linum L.; in vitro; nuтательная среда; фитогормоны; побег.

Надійшла / Received 13.03.2019

Погоджено до друку / Accepted 14.05.2019 